\title{
Sosiaalipedagogiikka ja sen uudet sovellukset
}

\author{
Leena Kurki
}

\author{
Moderneissa sosiaalipedagogiikan keskusteluissa \\ pohditaan erityisesti, mitä on hyvä elämä ja miten \\ ihmistä autetaan ottamaan vastuuta arkipäivästään \\ (elämismaailmastaan), nousemaan apatiasta \\ hallitsemaan elämäänsä entistä paremmin sekä \\ rakentamaan yhteisöjään paremmiksi ja tavoittelemaan \\ sitä kautta solidaarisempaa ja oikeudenmukaisempaa \\ yhteiskuntaa. Arkipäivässä eläminen merkitsee samalla \\ uusien kokemusten vastaanottamista sekä kriittisen \\ ajattelukyvyn ja itsetietoisuuden kasvua.
}

Sosiaalipedagogisen ajattelun ja toiminnan synty liittyy niihin teollistumis-, kaupungistumisja modernisaatioprosesseihin, jotka alkoivat 1800 -luvulla muovata koko eurooppalaista yhteiskunnallista kenttää. Käsitteenä sosiaalipedagogiikka on esiintynyt ensimmäisen kerran yhteiskunnallisessa ja tieteellisessä keskustelussa Saksassa 1840luvalla. Tieteellinen sosiaalipedagogiikka kehittyi uuden, ihmisen rationaalisuutta, autonomiaa ja vastuuta korostavan ihmiskuvan perustalle. Tämä uuden ajan ihmis- ja yhteiskuntakäsitys viritti sellaista tietoista sosiaalista toimintaa, jossa yhdistyivät kristillinen lähimmäisenrakkaus ja valistuksen kehitysuskoon perustunut kasvatusoptimismi. Huono-osaisuutta ei pidetty enää ihmisen kohtalona, vaan yhteiskunnallisena epäkohtana, jota voidaan suunnitelmallisesti ehkäistä ja lievittää. (Hämäläinen ja Kurki 1997, 11-12.) Saksalaisen sosiaalipedagogiikan kehityksessä on ollut useita vaiheita, jotka ovat heijastaneet yhteiskunnan kulloistakin tilannetta. Ensimmäises- sä vaiheessa Paul Natorp oli vahvin teorian luoja ja siitä lähtien ovat käsitteet "yhteisö" ja "tahto" jääneet sosiaalipedagogiikan keskeisiksi käsitteiksi. Toisen vahvan sosiaalipedagogin Herman Nohl'in ajattelusta jäi muun muassa "pedagogisen suhteen" analyysi myöhemmin yhdeksi sosiaalipedagogiikan ydinkysymyksistä. (Ks. tarkemmin Siljander 1987, 69-129.)

Maailmalla sosiaalipedagogiikka määrittyy monien eri traditioiden kautta. Saksalaisen sosiaalipedagogiikan ohella omaleimaisin traditio on romaanisella kielialueella. Tosin modernissa saksalaisessa sosiaalipedagogiikassakin on varsin monia paradigmoja yhteiskuntaan integroitumista korostavista yhteiskunnalliseen transformaatioon suuntautuviin varsin kriittisiin näkökulmiin saakka. Romaanisella kielialueella, erityisesti latinalais-amerikkalaisessa traditiossa, painottuu erityisesti yhteiskunnan laadullinen muuttaminen. Sosiaalipedagogiset toimijat voivat tuolloin työs- 
kennellä esimerkiksi vapaaehtoisina lukutaidon opettajina Brasiliassa, köyhien ja sorrettujen puolustajina Meksikossa, mutta myös ammattimaisina vapaa-ajan ohjaajina Ranskassa, matkailijoiden aktivoijina Tunisiassa, nuorisotyöntekijöinä Espanjassa, huumetyöntekijöinä Portugalissa ja niin edelleen.

$\mathrm{M}$ eitä lähinnä on Pohjoismainen sosiaalipedagogiikka, mutta se ei muodosta itsenäistä teoreettista traditiota, vaan tukeutuu lähinnä saksalaisiin tai latinalais-amerikkalaisiin keskusteluihin. Tanskalaisilla on tosin oma mallinsa, ns. Madsenin kukkanen. B. Madsen jakaa sosiaalipedagogisen toiminnan neljään alueeseen eli tuottavaan, eri tavoin ilmaisulliseen, kielellissosiaaliseen ja tieteelliskokeilevaan. Sosiaalipedagoginen toimintapätevyys yhdistää kyseiset alueet sillä tavalla, että sosiaalipedagoginen toimija saavuttaa persoonallisen suhteen ammatilliseen pätevyyteensä. Myös suomalaisissa ammattikorkeakouluissa Madsenin kukkasta on jo käytetty apuna erityisesti sosiaalipedagogisten opetussuunnitelmien laadinnassa. (Madsen 1995.)

$\mathrm{S}$ osiaalipedagogiikan määritteleminen on kuitenkin vaikeaa ja siksi vaarana on, että sosiaalipedagogiikaksi voidaan sanoa myös monenlaista puuhastelua. Jo käsitteen kahdella ulottuvuudella, pedagoginen ja sosiaalinen, on monenlaisia määrityksiä. Joka tapauksessa oppialan perusolemus on juuri sosiaalisen ja pedagogisen yhdistymisessä.

Moderneissa sosiaalipedagogiikan keskusteluissa pohditaan erityisesti, mitä on hyvä elämä, ja miten ihmistä autetaan ottamaan vastuuta arkipäivästään (elämismaailmastaan), nousemaan apatiasta hallitsemaan elämäänsä entistä paremmin sekä rakentamaan yhteisöjään yhä paremmiksi ja sitä kautta tavoittelemaan solidaarisempaa ja oikeudenmukaisempaa yhteiskuntaa. Arkipäivässä eläminen merkitsee samalla uusien kokemusten vastaanottamista sekä kriittisen ajattelukyvyn ja itsetietoisuuden kasvua. Yksilön oman elämänperspektiivin rakentuminen on arkipäivän toiminnassa oleellista, eikä sitä enää voida yhteiskunnallis-institutionaalisesti ohjailla yksityiskohtaisesti. Se rakentuu koko ajan uusista sosiaalisis- ta ja samalla vahvasti yksilön persoonasta ponnistavista piirteistä. Elämänperspektiivillä on siis sekä sosiaaliset että persoonalliset ulottuvuutensa. Arkipäivän analyyseihin liittyvät myös kysymykset ihmisten yhteisesti jakamasta arjesta. Siksi yhteisöllisyyden ongelmat, ihmisen ja yhteiskunnan monimuotoinen suhde, ovatkin sosiaalipedagogiikan ydinkysymys. (Ks. Böhnisch ja Münchmeier 1993, 54-56; Mollenhauer 1991; Thiersch 1986; vrt. Suomessa esim. Roos 1996; Sallila ja Vaherva 1998.)

Sosiaalipedagogiikka on eettinen ja myös ideologinen ajattelun tapa. Juuri ideologian avulla filosofia ja sosiaalipedagoginen teoria kääntyvät toiminnaksi, aidoksi dialektiseksi praksikseksi, vuorovaikutukseksi teorian ja käytännön välillä. Sosiaalipedagoginen diskurssi juurtuukin yleiseen ideologiseen diskurssiin eli pohditaan, pitääkö vallitseva järjestys - yhteiskunta - säilyttää sellaisena, kuin se on, vai pitääkö sitä muuttaa. Myös yksilön ja yhteiskunnan välistä suhdetta pohditaan joko yhteiskuntaa säilyttävänä tai sitä muuttavana suhteena. (vrt. Macridis ja Hulliung 1998, 15.)

Q osiaalipedagogiikassa keskitytään kahteen asiOan. Toisaalta on kyse ihmisen sosiaalisen muotoutumisen auttamisesta, sosialisaation tukemisesta; miten ihmisestä kasvatuksen avulla tulee yhteiskunnan toimiva jäsen. Toisaalta sosiaalipedagoginen toiminta keskittyy erityisesti syrjäytyneiden, yksinäisten ja puutteenalaisina elävien ihmisten tarpeisiin ja niiden tyydyttämiseksi välttämättömän yhteiskunnallisen muutoksen aikaansaamiseen. Sosiaalipedagogiikan avulla pyritään rakentamaan perusteita sille inhimilliselle emansipaatiolle, joka tarvitaan perustaksi humaa- 
nin ja oikeudenmukaisen yhteiskunnan luomisessa. Suuntaudutaan erityisesti ihmisten vapaaaikaan eli muodollisen koulutusjärjestelmän ulkopuolella tapahtuvaan monimuotoiseen pedagogiseen toimintaan. Oppimisen informaali puoli korostuu.

Sosiaalipedagogiikalla on historiansa kuluessa tarkoitettu monia asioita. Yhtäältä se on ymmärretty koko yhteiskunnallisen elämänmuodon läpäisevänä periaatteena, jossa korostuu ajatus inhimillisyyden, henkisten arvojen ja yhteisöllisyyden edistämisestä pedagogisin keinoin. Toisaalta sitä on pidetty yhteiskunnallisena liikkeenä, joka korostaa kasvatuksellisia näkökohtia yhteiskunnallisten uudistusten toteutuksessa. Kolmanneksi se ymmärretään itsenäisenä tieteellisenä oppialana tai tieteellisen pedagogiikan yleisperiaatteena tai osa-alueena. Vielä sosiaalipedagogiikka on nähty ensisijaisesti pedagogisin keinoin tapahtuvana sosiaalisten ongelmien lievittämiseen tähtäävänä työnä ja toimintajärjestelmänä ja tähän liittyvänä koulutuksena. (Hämäläinen 1995, 295.)

Sosiaalipedagogiikka ei ole kasvatustieteessä mikään uusi asia. Esimerkiksi Vives, Comenius, Rousseau, Pestalozzi, Kerschensteiner, Grundtvig, Makarenko, Dewey, Knowles ja monet muut ovat myös sosiaalipedagogiikan klassikkoja. Kaikki he ovat olleet kasvatusoptimisteja, jotka uskoivat kokemisen, osallistumisen ja tekemisen merkitykseen sekä pohtivat kukin omalla tavallaan kasvatuksen eettisiä ja normatiivisia sisältöjä. (vrt. Quintana 1999.)

\section{Aikuiskasvatus ja sosia a lipedagogi i ka}

osiaalipedagogiikka käsittää koko ihmisen elävain sen aikuiskasvatuksellisiin yhteyksiin. Sosiaalipedagogiikka liittyykin kaikkiin aikuiskasvatuksen osa-alueisiin eli peruskoulutukseen, ammatilliseen koulutukseen, elinikäiseen oppimiseen sekä aivan erityisesti sosiokulttuuriseen toimintaan. Sosiaalipedagogisia sisältöjä on erityisesti käsitteissä jatkuva ja elinikäinen oppimi- nen ja kasvu sekä yhteisötyö ja andragogiikka. Lisäksi informaatioyhteiskunnan tarpeisiin vastaaminen ja siinä tarvittavien kykyjen kouluttaminen on luonut aikuiskasvatuksen sosiaalipedagogiikalle uuden vaativan työkentän. Informaatioyhteiskunnan myötä on tapahtunut paljon muutoksia, työpaikat ovat vähentyneet ja yhteiskunnallinen eriarvoisuus on lisääntynyt. Se on tuonut mukanaan yhä enemmän sosiaalista ja kulttuurista syrjäytyneisyyttä. (López Palma ja Flecha 1997, 154-170; Fernández Arenaz 1994, 167.)

$\mathrm{M}$ oderni aikuiskasvatuskeskustelu asettuu selvästiklassiselle educare-educere-akselille. Passivoivan ja ulkoapäin ohjaavan educare kasvatuksen sijaan se suuntautuu yhä tietoisemmin kohti educere-kasvatusta, jonka herätteet ovat itsekasvatukseen ja vapaaseen tahtoon perustuvia. Kasvatettava itse on oleellinen eli lähdetään jokaisen ihmisen, hänen ainutlaatuisen persoonansa huomioonottamisesta. Didaktinen tyyli on aktiivinen ja perustuu kaikkiin aktiivisiin ja osallistaviin pedagogiikkoihin. (Merino 1997, 99102.)

Modernin aikuiskasvatuksen ja sosiaalipedagogiikan keskustelut ovat siis varsin lähellä toisiaan, aikuiskasvatuksen luonnehdinnat ovat myös sosiaalipedagogiikan luonnehdintoja (Quintana 1986, 11-12; 1992, 13). Molemmat ovat osallistavia. Tietojen vertikaalinen välittäminen hylätään ja ymmärretään, että opiskelijat ovat omassa oppimisessaan subjekteja ja aitoja toimijoita. He ottavat osaa itseään koskevaan päätöksentekoon kaikissa oppimisprosessin vaiheissa. Oppija on aktiivinen. Hän ei pelkästään omaksu passiivisesti kulttuurisisältöjä vaan luo itse omaa arkipäiväänsä ja sitä kautta kulttuuriaan. Aikuiskasvattaja ei ole tietojen jakaja vaan hän on innostaja (fasilitaattori, mentori, koordinaattori), joka auttaa yksilöitä ja ryhmiä saamaan oppimisen prosesseja liikkeelle. Oppimisessa on persoonan kehittymiseen tähtäävän tavoitteen lisäksi aina mukana myös yhteisöllinen, sosiaalinen dimensio. Oppijat kohtaavat ja löytävät itse omat tarpeensa, omat ongelmansa, joita haluavat ratkaista. Sitä kautta he kehittävät yhä täydemmän ja paremman tavan elää, eikä tämä kosketa vain yksilölli- 
siä tarpeita vaan koko yhteisöllistä elämää. Sosiaalipedagogisesti painottuneessa aikuiskasvatuksessa korostuu yksilön persoonallinen arvokkuus, hänen kykynsä ja oikeutensa löytää itse elämänsä suunta ja tarkoitus. Samalla kuitenkin ajatellaan, että persoona kasvaa täyteyteensä vain eläessään yhdessä toisten, yhtä arvokkaiden persoonien kanssa. Yhteisen toiminnan tavoitteena on sosiaalisen todellisuuden transformaatio eli laadullinen muuttaminen. Ihmiset heräävät tietoisuuteen todellisuudestaan, heillä kehittyy kyky tehdä päätöksiä tuon todellisuuden parantamiseksi, ja he sitoutuvat todellisuutensa laadulliseen muuttamiseen.

Sosiaalipedagogisesti aikuiskasvatus ymmärretään ensisijaisesti tiedostamisen, muutoksen ja sosialisaation välineenä. Arkipäivän toiminnan avulla tavoitellaan sellaisen kasvattavan yhteiskunnan luomista, joka perustuu solidaarisuuden arvoihin. Ihmistä tuetaan valmistautumaan tuottavaan elämään, osallistumiseen ja yritteliäisyyteen. Sosiaalipedagoginen aikuiskasvatus koskettaa ihmistä kokonaisuudessaan, se kattaa työn, vapaa-ajan sekä perhe-elämän, ja sen tavoitteena on kehittää ihmisen sekä fyysisiä, älyllisiä että moraalisia taipumuksia ja kykyjä. Aikuiskasvatus on väline taistelussa kulttuurista ja taloudellista vieraantuneisuutta vastaan. Sen avulla luodaan vapauttavaa ja aitoa kulttuuria. Vaikka sosiaalipedagogiikka ei tuokaan aikuiskasvatukseen mitään olennaisesti uutta, se korostaa tiettyjä sisältöjä, joista esimerkiksi pedagogisen suhteen analyysi voi tuoda myös aikuiskasvatuksen keskusteluun aivan uusia painopisteitä.

\section{Sosiokulttuurinen innostaminen a iku is kasvatuksen ideologiana ja metodologiana}

$\mathrm{R}$ anskalainen sosiaalipedagogiikka, sosiokulttuurinen innostaminen (animation socioculturelle) erityisesti latinalais-amerikkalaisine ja espanjalaisine painopistealueineen (animación sociocultural) tuo myös suomalaiseen aikuiskasvatukseen selkeästi uusia tuulahduksia ja analyysivälineitä (vrt. Requejo Osorio 1997, 252-253).
Sosiokulttuurinen innostaminen on pedagoginen tiedostamisen, osallistumisen ja luovuuden liike, jolla on Keski-Euroopassa ja Latinalaisessa Amerikassa jo suhteellisen pitkä perinne. Se syntyi sekä käsitteenä että toimintana Ranskassa toisen maailmansodan jälkeen, jolloin innostaminen löydettiin demokraattisten arvojen elvyttämisen tehokkaaksi välineeksi lähinnä työväestön kouluttamiseen ja vapaa-ajan toimintaan keskittyneen education populaire -liikkeen kautta. Toiminnan tavoitteena on alusta lähtien ollut sekä yksilön persoonallinen että yhteisöllinen kehitys. Ammattina innostaminen syntyi 60-luvulla vapaaehtoistyön pohjalta. Myös Unesco otti käsitteen omakseen 60-luvulla ja sitä kautta innostaminen alkoi voimakkaasti levitä aluksi lähinnä ranskaa puhuvilla alueilla Euroopassa, Kanadassa ja Afrikassa. Myöhemmin se levisi nopeasti espanjan-, portugalin- ja italiankieliseen maailmaan.

$\mathrm{M}$ yös Latinalaisessa Amerikassa innostaminen levisi voimakkaasti educación popular liikkeen kautta, joka on alusta lähtien ollut paljon radikaalimpi liike kuin ranskalainen kaimansa. Saksalaisella kielialueella innostamiseen liittyvää keskustelua käydään sosiaalipedagogiikan yhteydessä, ja anglo-amerikkalainen diskurssi löytyy community development tai popular education otsikoiden alta sekä empowerment analyyseista. (Kurki 2000; vrt. Besnard 1991; Gillet 1995.)

I nnostamisella on kaksi päätavoitetta. Ensinnäkin sen avulla herätetään henkiin elämää siellä, missä sitä ei ole, luodaan liikettä, huolestuneisuutta, levottomuutta ja tuetaan aloitteellisuutta, asioiden täytäntöönpanoa, itsenäistä toimintaa ja vastuuntuntoa. Toinen tavoite on tukea ja saada liikkeelle niitä kykyjä, jotka jo ovat olemassa, vaikka ne olisivatkin heikot ja tiedostamattomat. Motivoidaan, herätetään, vahvistetaan ja koordinoidaan yksilöiden ja ryhmien kykyjä ja voimia sekä heidän osallistumistaan sosiaaliseen, kasvatukselliseen ja kulttuuriseen toimintaan. Innostamisella onkin kolme sisällöllistä ulottuvuutta, kasvatuksellinen, sosiaalinen ja kulttuurinen, jotka kaikki ovat läsnä innostamisen prosessissa, tilanteesta riippuen aina hieman eri painotuksin. 
Merino (1997; 34-36) nostaa innostamisen perusteiksi kolme avainkäsitettä, jotka juurtuvat eri traditioihin. Ensimmäinen niistä on "antaa elämä, innostaa" (animar). Se nousee lähinnä ranskalaisesta innostamisnäkemyksestä ja viittaa persoonallisen, inhimillisen yhteisön ja yhteiskunnan rakentamiseen ja hyvän arkipäivän elämänlaadun tavoittamiseen. Innostajat saattavat ihmisiä yhteen toistensa kanssa ja tukevat kulttuurista luovuutta ja moniarvoisuutta. Ryhmätasolla innostamisen avulla motivoidaan ryhmäprosessien liikkeelle lähtemistä sekä yksinkertaistetaan rakenteita ja toimintoja sellaisiksi, että ne auttavat ryhmien itseohjautuvuutta. Samalla tuetaan paikallisen kulttuurin ilmiöitä.

Toinen käsite eli "välittää, ryhtyä välittäjäksi" (intervenir) on puolestaan lähellä tiettyjä anglosaksisia yhteisön kehittämisen ja verkostotyön muotoja (community development, popular education). Innostamisen tavoitteena on synnyttää aidon yhteistyön verkoissa ja projekteissa toimivia oma-aloitteisuuden ryhmiä. Toiminta tapahtuu siten, että tehokkaiden paikallisten ohjelmien avulla tuetaan ihmisten omaa luovaa osallistumista. Työmuotoina käytetään erilaisia aktiivisten pedagogiikkojen muotoja.

Kolmas käsite, "muuttaa laadullisesti" (transform$a r$ ), on toisaalta selkeästi latinalais-amerikkalainen käsitys innostamisesta, mutta samalla se heijastaa innostamisen yleistä viimeaikaista keskustelua. Toiminnan päämääränä on muutos kohti solidaarista mielenlaatua ja solidaarisia asenteita sekä kohti koordinoituja, tasavertaisia ja hajautettuja, vähemmän byrokratisoituneita, keskitettyjä ja hierarkkisia tilanteita. Käytännössä asenteita ja tilanteita pyritään muuttamaan passiivisista aktiivisiksi, yksilökeskeisistä osallistuviksi, eristäytyneistä solidaarisiksi, konformistis-vastaanottavista luoviksi, aloitteellisiksi ja innovatiivisiksi. Autoritaarinen ja yksisuuntainen metodologia muutetaan osallistavaksi ja tieteidenväliseksi.

Klassisen educere-mallin kautta myös innostaminen on vahvasti esillä aikuiskasvatuksen uusissa eurooppalaisissa linjauksissa. Aikuiskasvatuksen tehtävä on tuolloin erityisesti syrjäytyneessä ase- massa olevien ihmisten ja ryhmien kykyjen voimistaminen niin, että he kykenevät osallistumaan, kommunikoimaan ja sitä kautta reflektoivasti, pohdiskelevan havainnoivasti tiedostamaan ympäristöään. Tavoitteena on ihmisten oppimiskyvyn kehittyminen: opitaan ajattelemaan, toimimaan ja luomaan. Pyritään siihen, että ihmisellä olisi kykyä ja uskallusta elää elämäänsä mahdollisimman täydesti modernissa yhteiskunnassa ja sen kiihtyvässä muutoksessa. Sosiokulttuurinen innostaminen tuo tähän prosessiin erityisen motivoivan elementin auttaessaan taistelussa kohtalonuskoa ja apatiaa vastaan ja innostaessaan oppimaan koko elämän ajan. Siinä, missä innostaminen luo kokonaan uusia kasvatuksellisia järjestelmiä yhdistäessään rakenteissaan kasvatuksellisen, kulttuurisen ja sosiaalisen ulottuvuuden, toimii perinteinen jatkuvan kasvatuksen ajatus kuitenkin lähinnä olemassaolevien kasvatusjärjestelmien parantamiseksi. (Froufe ja Sánchez 1992; Ucar 1992, 41-43; Ventosa 1993, 86-87.)

\section{Paulo Freire ja sosio- kultuurinen innostaminen}

$\mathrm{M}$ odernilla aikuiskasvatuksella ja sosiokulttuurisella innostamisella on yhteinen tavoiteohjelma. Sen vahvin suunnannäyttäjä on ollut brasilialainen Paulo Freire (1921-1997). Tämä yhteinen ohjelma perustuu ajatukseen, että yhteiskuntaa pitää muuttaa. Muutoksen pitää tapahtua sellaisen vapautuksen hengessä, joka vapauttaa ihmisen kaikesta syrjäyttämisestä, tukahduttamisesta ja alistamisesta. Muutos lähtee liikkeelle siitä, että ihminen on herännyt tietoisuuteen paremman todellisuuden saavuttamisen mahdollisuudesta. Tietoisuuden heräämisestä seuraa välttämättä transformatiivista toimintaa: ihmiset sitoutuvat yhteiseen toimintaan todellisuutensa laadulliseksi muuttamiseksi. (Vrt. Quintana 1992, 17.)

Innostamisen transformatiivinen tulkinta on lähtöisin latinalais-amerikkalaisesta, ihmisen tietoisuuden heräämiseen tähtäävästä educación popularista. Sekä innostamisen että educación popularin lähtökohta on näkemys dialektisesta vuorovaikutuksesta kasvatuksen, kulttuurin ja yhteiskunnan 
välillä. Dialogin käsite on tämän vuorovaikutuksen ytimessä etsittäessä strategioita aidon inhimillisen vapautuksen syntymiseen. Ymmärretään, että ihminen on organismi, joka on ohjelmoitu oppimaan, eikä ole olemassa mitään ennalta määrättyä kohtaloa. Dialogin käsite konkretisoituu vuoropuhelussa ihmisten ja ihmisen ja maailman välillä, ja kyseisen dialektiikan avulla myös kasvatus ja koulutus voivat toimia sosiaalisten utopioiden rakentajina.

Freireläinen toiminta perustuu siis ihmisten omaan osallistumiseen, dialogiin ja päätöksentekoon. Toiminnassa on aina kolme vaihetta. Ensimmäinen vaihe on todellisuuden tutkiminen ja sen kriittinen analyysi. Toisessa vaiheessa nähdään edelliseen perustuva kriittinen visio, utooppinen unelma paremmasta todellisuudesta. Kolmanneksi etsitään välineet, joita tarvitaan tiellä tähän parempaan todellisuuteen, ja sen jälkeen sitoudutaan todellisuutta laadullisesti muuttavaan (transformatiiviseen) toimintaan. Koko ajan toiminnassa nousee samalla esiin uusia ratkaistavia ongelmia, joten todellisuuden muuttaminen paremmaksi, inhimillisemmäksi ja oikeudenmukaisemmaksi on päättymätön prosessi. - Myös "opettaja" on tässä prosessissa aina oppija, jonka erityinen tehtävä on tuntea oppilaidensa arkipäivän elämä.

vainkäsite freireläisessä pedagogiikassa on - conscientizacâo, joka varsin epätarkasti käännettynä merkitsee syvää, erityislaatuista tiedostamista. Ihmisiä täytyy opettaa kriittisiksi, sillä ihmiset voivat tulla subjekteiksi kriittisen reflektion avulla, joka johtaa tietoisuuden heräämiseen. Freireläinen metodi onkin ongelmakeskeinen, se yhdistyy ihmisten omiin jokapäiväisiin ongelmiin ja laajenee niistä yhä laajemmille tasoille. Lopullisena tavoitteena on, että ihmiset siirtyvät niin sanotun transitiivisen kriittisen tietoisuuden asteelle, jolloin he kykenevät tulkitsemaan ongelmia syvällisesti ja vapauttamaan itsensä hiljaisuudesta ja passiivisuudesta. He ovat dialogisia ja avoimia tilanteiden uudelleen arviointiin. He myös kieltäytyvät siirtämästä vastuuta. Siirtyminen kyseiselle tietoisuuden tasolle on välttämätöntä vapautuksen prosessin onnistumiseksi.
Freire siis uskoo, että tukahdutettu, syrjäytetty ihminen voi itse löytää omat olosuhteensa ja kukistaa ne reflektiivisesti, pohdiskelevasti, havainnoiden oman historiallisen kohtalonsa subjektina, ajattelevana ja toimivana olentona. Tämä ihmisen vapautus ei kuitenkaan tapahdu pelkästään tietoisuuden heräämisen avulla, vaan siihen liittyy aina sitoutuminen sellaiseen toimintaan, jonka lopullinen tavoite on epäoikeudenmukaisten yhteiskunnallisten rakenteiden muuttaminen. (Ks. Freiren ja innostamisen yhteydestä tarkemmin esimerkiksi Kurki 2000; Hämäläinen ja Kurki 1997, 207-214.)

Freireläisen vapautuksen kasvatustieteen (educación liberadora) metodologia on aina myös innostamisen metodologinen ydin. Myös innostamisen perimmäinen tavoite on kulttuurisen demokratian saavuttaminen. Kulttuuri ymmärretään tuolloin persoonallisena ja kollektiivisena kohtalon luomisena. Ajatellaan, että ihminen ei ole vain kulttuurinsa tuote vaan myös sen luoja.

Kulttuurisen toiminnan pitää olla demokraattista, yhteisöllistä, ihmisiä ja yhteisöjä integroivaa toimintaa. Osallistuminen ja luovuus ovat sen avainkäsitteet. Samalla tässä kulttuurisen demokratian näkemyksessä, transformatiivisessa käsityksessä kulttuurista, korostuu ihmisten arkipäivän toiminnan merkitys ja tunnustetaan jokaisen ihmisen kyvyt ja mahdollisuudet toimia oman elämänlaatunsa luojana ja aktiivisena osallistujana yhteisönsä kehitykseen.

Kulttuurisen demokratian saavuttaminen on välttämätön perusta myös poliittiselle ja taloudelliselle demokratialle. Kulttuuripolitiikka liittyykin koko elämänlaadun problematiikkaan. Kaikille ihmisille tulee taata "pääsy kulttuuriin", mutta ei niin, että saavutetaan pelkkiä kulttuurisia tietoja, vaan omaksutaan sellainen elämäntyyli, joka tarkoittaa jokapäiväisen elämän haltuunottoa ihmisen persoonallisen itsetoteutuksen kenttänä. Yhteiskunnan kehitys ymmärretään kulttuurin kehityksenä, joka toteutuu erityisesti ihmisten ja yhteiskunnan välisten suhteiden laadussa, siinä millainen on ihmisten autonomian aste ja heidän kykynsä löytää paikkansa maailmassa. Miten he kykenevät vuorovaikutukseen toistensa 
kanssa ja samalla kiinnittymään enemmän yhteiskuntaan ja toisaalta vapautumaan siitä? (AnderEgg 1992; 1997; Pérez de Cuellar et al. 1998, 15.)

\section{Innostaminen on toim in tat ut kim us ta}

$I$ nnostamisen kokonaisuudessa on kolme elementtiä. Sen perusta on teoreettis-ideologinen ja tuosta perustasta nousee se metodologinen orientaatio, johon käytännön toiminta, metodit, juurtuu. Innostamisen metodologinen lähtökohta on aina ihmisten oma osallistuminen. Varsinkin latinalais-amerikkalaisesta perspektiivistä tarkasteltuna innostamista ohjaakin selkeä paradigma. Sen tiedonintressi on teoreettis-käytännöllinen eli ihmisen todellinen vapautus. Tällöin peruslähtökohta on käytäntö eli ihminen toimimassa omassa historiallis-yhteiskunnallisessa todellisuudessaan. Tietoon liittyy aina kysymys tarkoituksesta: mitä varten ihminen elää? Tieto itsessään ei ole ongelma, vaan olennaista on, millainen on tiedon suhde todellisuuteen. Siksi sekä innostamiseen liittyvässä tutkimustyössä että käytännön toiminnassa täytyykin aina olla osallistava elementti: syrjäytyneet ja tukahtuneet ihmiset luovat itse tietoisuuttaan olla muutoksen toimeenpanijoita, ja tietoisuuden herätessä he myös sitoutuvat toimintaan tuon muutoksen aikaansaamiseksi.

Käytännössä innostamisen toiminnan osallistava metodologia tarkoittaa yksinkertaisesti sitä, että ihmiset toimivat vuorovaikutuksessa toistensa kanssa yhteisen päämäärän suuntaan. Innostamisen tavoite on saada aikaan tuon toiminnan, osallistumisen, avulla muutoksia yhteiskunnassa.

Innostaa voidaan hyvin monella alueella. On kulttuurista, kasvatuksellista, urheilullista, yhteisöllistä, vapaa-aikaan, turismiin, yritystoimintaan ja niin edelleen liittyvää innostamista. Kuitenkin innostaminen on aina ryhmien ja niihin kuuluvien ihmisten liikkeelle saattamista. Sosiaalisilla interventioilla voikin olla monia metodologisia kehyksiä, eivätkä mitkään metodit itsessään ole sosiaalisen muutoksen välineitä. Siksi tutkimuksellinen ote on innostamisessa oleellista. Se on osa kasvatuksellista prosessia eikä vain jotakin irrallista tai johonkin erityiseen vaiheeseen kuuluvaa toimintaa. Myös tutkimuksen tulee aina olla osallistavaa eli sen toteuttajina ovat samat ihmiset kuin tutkimuksen "kohteenakin"; tavoitteena on tietoisuuden lisääminen juuri näiden ihmisten omasta todellisuudesta. Pyrkimyksenä ei siten ole pelkästään "saada tietää", vaan tavoitteena on myös analysoida, tulkita ja asettaa tämä todellisuus erilaisiin suhteisiin, jotta sitä kyettäisiin ymmärtämään.

$\mathrm{P}$ arhaimmillaan innostaminen on siis aitoa toimintatutkimusta, kuten sitä on parhaimmillaan myös jatkuva ja elinikäinen oppiminen. $\mathrm{Ne}$ tähtäävät muutokseen ja lähtevät niistä ongelmista, joita tutkimukseen osallistujat itse elämässään kokevat ja tuntevat. Tutkimukseen osallistuvan ryhmän jäsenet ovat aktiivisina tutkijoina mukana ongelman määrittelystä tavoitteiden asettamiseen, tutkimuksen vaiheiden suunnitteluun, toteuttamiseen ja tulosten arviointiin saakka. Osallistuminen on niin oleellinen osa innostamista, että jos eivät ihmiset itse ole mukana päätöksenteossa toiminnan kaikissa vaiheissa, on kyse jostakin muusta kuin sosiokulttuurisen innostamisen toiminnasta.

Toimintatutkimuksen määrittely ei kuitenkaan ole helppoa, sillä toimintatutkimus on paremmin ajattelun malli kuin tekniikka. Kyseessä on eettinen sitoutuminen, joka lähtee yhteistyöstä ja tähtää sosiaalisen todellisuuden parantamiseen. Tutkimukseen osallistuvassa ryhmässä pyritään saamaan aikaan kykyä ja uskallusta omaa todellisuuttaan koskevaan kriittiseen reflektointiin.

Innostamisella ei ole omia toimintamenetelmiä, vaan ne haetaan eri tieteiden alueilta. Sopivia ovat kaikki ne menetelmät, joiden avulla ihmiset saadaan vuorovaikutukseen toistensa kanssa. Menetelmälliset valinnat nousevat innostamisessa kuitenkin aina teoreettis-ideologisesta kehyksestä. Kehyksiä voi olla monia, mutta ranskalainen J-C Gillet (1995) on taidokkaasti yksinkertaistanut innostamisen kaksi pääorientaatiota otsikoiden ne innostamisen kuumaksi ja kylmäksi maailmaksi. Se, kummassa maailmassa kulloinkin eletään, vaikuttaa suuresti sekä innostamisen metodologiaan että valittaviin työmenetelmiin. 
I nnostamisen kylmässä teknisessä maailmassa suuntaudutaan yhteiskunnan säilyttämiseen sellaisena kuin se on, ja taloudelliset näkökohdat ovat ensisijaisia. Siinä pyritään vaikuttamaan sosiaalisen epätasa-arvon seuraamuksiin, ei syihin. Kylmä maailma rakentuu illuusioille ja sellaisen humanistisen ja idealistisen keskustelun ympärille, jonka avulla ainoastaan naamioidaan piiloon ne sosiaaliset voimat ja rakenteet, jotka yhteiskunnassa todella vaikuttavat. Innostaminen on sosiaalisen kiinteyden väline, joka suuntaa ihmisten energioita kohti konsensusta ja status quota. Järjestys välitetään kansalle ylhäältä alas, innostamisen toiminta on yhteiskunnan teknostruktuurin uskollinen palvelija, ja innostajat ovat ammattilaisia, jotka ovat sokeutuneita toimintansa merkityksettömyydelle. Innostaja onkin vain yksi lisä ihmissuhdeteknikkojen armeijaan yrittämässä solmia kommunikaation lankoja ihmisten välille.

Kuuma maailma sitä vastoin on reaktio hallitsevia ja tukahduttavia järjestelmiä vastaan. Yhteiskuntaa pyritään muuttamaan. Kuuma maailma on sosiaalisen vastarinnan liike, joka suuntautuu markkinataloutta, keskiluokkaisuutta, passiivisuutta, välinpitämättömyyttä, byrokratiaa, teknokratiaa, konformistisuutta ja yhteiskunnan yksiulotteisuutta vastaan. Innostaminen on tiedostavaa kasvatuksellista toimintaa. Osallistumisen ymmärretään olevan lääke siihen sosiaaliseen patologiaan, joka ajassamme vallitsee. Innostaminen suuntautuu ihmisen jokapäiväisen elämään, kohti jokaisen ihmisen sekä persoonallista että kollektiivista osallistumista ja sitä kautta kohti ihmisten tietoisuuden heräämistä. Innostajalla on kyky johdattaa ihmiset analysoimaan omia kokemuksiaan ja panemaan ne vastakkain muiden kokemusten kanssa, jotta ihminen kykenisi ymmärtämään oman paikkansa ja päämääränsä ihmiskunnan kollektiivisessa historiassa, luomaan tietoista solidaarisuutta ja kieltäytymään välinpitämättömyydestä.

Nämä molemmat maailmat näkyvät modernissa 90-luvun innostamisessa, osittain vastakkaisina, osittain toisiaan täydentäen. Molempia myös tarvitaan, toisaalta liikkeelle saattamista, militanttia osallistumista, mutta toisaalta myös näin synty- neiden uusien voimien sääntelyä ja institutionalisointia.

\section{Sosiokult u u rinen \\ innostaminen ja suomalainen aikuiskasvatus}

$\mathrm{S}$ osiaalipedagogiikka ei Suomessa ole uusi asia, vaikka se käsitteenä onkin ollut syrjässä viime aikoihin asti. Professori Matti Koskenniemi aukaisijo väitöskirjassaan Soziale Gebilde undProzesse in der Schulklasse (1936) tietä sosiaalipedagogiikalle, mutta vasta teoksissa Kansakoulun opetusoppi(1943)ja Sosiaalinen kasvatus koulussa(1952)Koskenniemi esitti varsinaisen sosiaalipedagogisen ohjelmanjulistuksen. Tosin hän kehitti teoriaansa tämän hetkisestä eurooppalaisesta traditiosta poiketen koululuokan eli muodollisen koulutusjärjestelmän piirissä. - Ehkä olisikin syytä palata pohtimaan sosiaalipedagogiikan sovellusmahdollisuuksia koulussa. Esimerkiksi monet pajakouluhankkeet antavat siihen jo hyviä viitteitä.

Koskenniemeläistä sosiaalipedagogiikkaa seurasi kuitenkin tieteellisessä keskustelussa hiljaisuus, ja vasta viime vuosina on alettu laajemmin kehitellä sosiaalipedagogistyyppisiä pohdiskeluja. Silti sosiaalipedagogiikka ei ole saanut merkittävää jalansijaa suomalaisessa kasvatustieteessä.

Sosiokulttuurinen innostaminen on suomalaisessa keskustelussa vielä sosiaalipedagogiikan käsitettäkin huomattavasti uudempi käsite. Toimintana innostamisella on tosin myös täällä syvät juuret, vaikka suomalaisen innostamisen historia on toistaiseksi tutkimatta. Ehkä vanhin innostamisen muoto on ollut runonlaulu- ja arkkiviisuperinne. Myös monenlaiset elinkeinoihin liittyvät yhteistoimintamuodot sekä juhlat, leikit ja tarinat liittyvät samaan perinteeseen. Herätysliikkeet, raittiusliike ja työväenliike, harrastajateatteritoiminta, kansan- ja työväenopistot, naisten herääminen, kyläyhteisötoiminta, vapaapalokuntatoiminta, setlementtityö sekä osuustoiminta eri muotoineen ovat osa myöhempää suomalaista innostamisen historiaa. Ne kaikki vaikuttavat edelleen, ja lisäksi on syntynyt uusia kansalaistoiminnan muotoja, kuten työpajatoimintaa, työttömien osuuskuntia, urhei- 
lu- ja musiikkitoimintaa, yhteisöteatteria ja monenlaisia vapaaehtoisyhdistyksiä kolmannen sektorin käyttöön.

Nuorisotyöllä ja nuorisoseuraliikkeellä on erityisen kiinteä yhteys suomalaiseen innostamisen historiaan. Traditioon on sisältynyt kokemuksia moniarvoisesta, kansainvälisestä, lähiyhteisön tukeen nojaavasta ja yksilön itseohjaukseen perustuvasta kasvatustyöstä. Myös omiin elinolosuhteisiin vaikuttaminen on korostunut (Nieminen 1995, 414). Viime vuosikymmenien nuorisotyössä vahvan aseman saavuttanut yhteisökasvatuksen näkökulma on sekin puhdasta sosiaalipedagogiikkaa. Myös elämyspedagogiikan ja seikkailukasvatuksen yhteydet innostamiseen ovat ilmeiset.

uomalaisen aikuiskasvatuksen diskurssi on sitä messa valittiin kansansivistystyö aikoinaan aikuiskasvatuksen ydinalueeksi eikä aikuiskasvatuksen ranskalainen painopiste, innostaminen, saanut erityistä jalansijaa - joskin käytännön kansansivistystyön suhde innostamiseen on sisällöllisesti läheinen, ja myös freireläistä työtä on tehty (esimerkiksi Helena Kekkosen vankilatyö).

Nyt sekä kansansivistystyön käsitteitä että rakenteita ollaan kehittämässä selkeästi innostamisen suuntaan. Syksyllä 1999 pidettiin Tampereella ensimmäinen valtakunnallinen seminaari, joka kokosi yhteen vapaasta kansansivistystyöstä kiinnostuneita eri tieteenalojen edustajia. Työskentely on jatkunut ja sen tavoitteena on aloittaa laajamittainen tutkimustyö (työnimenä kansalaisyhteiskunta, demokratia ja kulttuuri), sillä vapaan sivistystyön keskeisiä peruskysymyksiä, kuten kansalaisten omaehtoista toimintaa, tasaarvoa, demokratian toteutumista ja kulttuuria sen yhteydessä on tutkittu vielä jokseenkin vähän.

Suomalaisessa aikuiskasvatuksessa on nykyisin laajasti nostettu esiin muitakin samantyyppisiä kysymyksiä. Siinä korostetaan yhä enemmän ihmisten arkipäivän kokemusten merkitystä, ja sosiaalisen oppimisen on sanottu soveltuvan jopa aikuiskasvatuksen uudeksi peruskäsitteeksi. Painotetaan elämänikäistä, ihmisten arkipäivän ympä- ristöissä tapahtuvaa oppimista. (Ks. esimerkiksi Sallila ja Vaherva 1998.) Kyseisessä aikuiskasvatuksen uusia keskusteluja etsivässä orientaatiossa on implisiittisesti selvä sosiaalipedagoginen painotus. Se avaa myös sosiokulttuuriselle innostamiselle mahdollisuuden muodostua aikuiskasvatuksen uudeksi ideologis-metodologiseksi strategiaksi. Sosiokulttuurinen innostaminen ja jatkuva kasvatus ovatkin osa samaa todellisuutta, saman kolikon kaksi puolta, eli ollakseen tehokasta elinikäinen, jatkuva kasvatus tarvitsee avukseen innostamisen politiikkaa (Ander-Egg 1997, 55-61).

Muutoinkin innostaminen on nyt tullut Suomeen yhä tiedostetummin. Keskustelut kansalaisyhteiskunnan ja kolmannen sektorin vahvistumisesta nostavat innostamisen aatteen välttämättä esiin, ja Vierumäellä koulutetaan jo liikunnan innostajia (animaattoreita). Myös viimeaikaisissa sosiaalityön ja yhdyskuntatyön virtauksissa innostamisen tyyppinen toiminta näkyy tietoisesti erityisesti monissa lähiöhankkeissa; Tampereen Haapalinnassa, Porin Sampolassa, Toijalan Rautalassa ja muuallakin.

Tampereen Haapalinnan lähiön ongelmien syntymistä ennaltaehkäisevä yhteisötyöprojekti perustuu Ahjolan setlementin pitkään sosiaalisen ja kulttuurityön perinteeseen. Työ perustuu setlementti-ideologiaan, joka jo traditioltaan on puhdasta sosiaalipedagogista ajattelua ja toimintaa. Toiminnan periaatteena on Haapalinnassa alusta lähtien ollut ihmisten oma osallistuminen kaikkeen toimintaan ja päätöksentekoon suunnittelusta ja tavoitteiden asettelusta arviointiin saakka. Alueelle on lyhyessä ajassa syntynyt monenlaista kulttuurista, sosiaalista ja pedagogista toimintaa, ja kansalaisopisto on mukana etsimässä sekin uusia yhteisötyön muotoja. Toijalan Rautalassa puolestaan alueen kehitystyö lähti vahvasti liikkeelle erityisesti yhteisöteatterin avulla. (Ks. teatterista innostamisen välineenä enemmän esimerkiksi Kurki 2000.) Innostamisen avulla eivät ongelmat kuitenkaan yksiviivaisesti ratkea ja niin Haapalinnassa kuin Rautalassakin tie on pitkä, hidas ja kivikkoinen. Yhä uusia ongelmia syntyy koko ajan, mutta myös se kuuluu kiinteästi innostamisen luonteeseen. 
Ainakin piiloisesti innostaminen on löytänyt tiensä myös virallisiin kulttuuripoliittisiin linjauksiin, kulttuurin ja luovuuden erityisprojektiin Keppiin (1998) ja vuonna 1992 valmistuneeseen Kupoli-mietintöön. Niissä kulttuuri ymmärretään laajasti käsittäen luovuuden, tieteen, taiteet ja henkiset voimavarat. Kannanotot perustuvat siihen, että eurooppalaiset asiantuntijat korostavat läheisiä yhteyksiä sosiaalisen, taloudellisen ja poliittisen toiminnan sekä taiteen ja kulttuurin välillä. Ymmärretään, että kulttuuripoliittinen kehitys suuntautuu väistämättä elitistisestä taiteen tekemisestä laajempien kansankerrosten aktivointiin, eli kulttuuri ymmärretään elämäntapana. Suomen Unesco-toimikunta on puolestaan julkaissut kulttuuriministerin allekirjoittamat lähtökohdat Suomen hallituksen kulttuuripoliittiselle toiminnalle otsikolla Kulttuurin voima - suunnitelmasta toimintaan (1999). Raportin mukaan toiminta tulee selvästi seuraamaan yleiseurooppalaisia innostamisen linjauksia.

Innostamisen mukaantulo aikuiskasvatuksen diskurssiin vaatii kuitenkin keskustelua myös aikuiskasvatuksen tieteellisestä olemuksesta. Innostamisen sosiaalitieteellinen olemus on selkeästi enemmän kvalitatiivinen kuin kvantitatiivinen; kyse on laadullisesta toiminnasta, osallistumisesta, sitoutumisesta ja tietoisuuden heräämisestä. Toiminnassa pyritään transformaatioon, laadullisen muutoksen aikaansaamiseen. Innostaminen on sosiaalipedagogiikkaa ja muun sosiaalipedagogisen toiminnan tavoin myös se on aina moraalista toimintaa. Sosiokulttuurinen innostaminen liittyy ajatukseen, että kaiken sosiaalisen työn perusta ja tehtävä on samalla tavalla laadullinen: kyse on aina ihmisten välisestä kohtaamisesta, palvelusta, dialogista ja solidaarisuudesta.

\section{Lähteet}

ANDER-EGG, Ezequiel (1992) Desarrollo y política cultural, Buenos Aires: Ciccus.

ANDER-EGG, Ezequiel (1997) Metodología y práctica de a animación sociocultural, Buenos Aires: Lumen

BESNARD, Pierre (1991) La animación sociocultural, Barcelona: Paidos

BÖHNISCH, Lothar ja MÜNCHMEIER, Richard (1993) Pädagogik des Jugendraums, Weinheim und München: Juventa.

FERNANDÉZ ARENAZ, Adalberto (1994) Educación de adultos, teoksessa Munoz Sedano, Antonio (ed.)
El educador social. Madrid: Editorial Popular.s.a., $163-175$.

FROUFE, Sindo ja SÀNCHEZ, María Angeles (1992) Animación sociocultural: nuevos enfoques, Salamanca: Amaru

GILLET, Jean-Claude (1995) Animation et animateurs, Paris: L'Harmattan.

HÄMÄLÄINEN, Juha (1995) Sosiaalipedagogiikan oppihistoriallinen kehitys Saksassa, Kuopion yliopiston julkaisuja E. Yhteiskuntatieteet 26.

HÄMÄLÄINEN, Juha ja KURKI, Leena (1997) Sosiaalipedagogiikka, Helsinki: WSOY.

KEPPI (1998) CD-ROM. Finland: Ministry of Education

KURKI, Leena (2000) Sosiokulttuurinen innostaminen - muutoksen pedagogiikka, Tampere: Vastapaino.

KOSKENNIEMI, Matti (1977, 1.p. 1952). Sosiaalinen kasvatus koulussa, Keuruu: Otava.

LÓPEZ PALMA, Fernando ja FLECHA, Ramón (1997) Educación de personas adultas, teoksessa Petrus Antonio (coord.) Pedagogía social. Barcelona: Ariel, 154-177.

MACRIDIS, Roy ja HULLIUNG, Mark (1998) Las ideologías políticas contemporáneas, Madrid: Alianza Editorial.

MADSEN, B. 1995. Socialpaedagogik og samfundsforvandling. Kopenhavn: Munksgaard.

MERINO FERNÀndEZ, José V. (1997) Programas de animación sociocultural, Madrid: Narcea

MOLLENHAUER, Klaus (1991) Einführung in die Sozialpädagogik, Weinheim und Basel: Beltz.

NIEMINEN, Juha (1995) Nuorisossa tulevaisuus: suomalaisen nuorisotyön historia, Jyväskylä: Lasten Keskus.

PĖREZ de CUELLAR, Javier (1998) Moninaisuus luovuutemme lähteenä. Kulttuurin ja kehityksen maailmankomission raportti. Helsinki: Otava.

QUINTANA, José María (1986) Investigación participativa. Educación de adultos, Madrid: Narcea.

QUINTANA, José María (1992) Fundamentos de Animación sosiocultural, Madrid: Narcea.

QUINTANA, José María (1999) Textos clásicos de pedagogía social, Valencia: NAU libres.

REQUEJO OSORIO Agustin (1997) Animación sociocultural y educación de adultos, teoksessa Trilla, Jaume. (coord.) Animación sociocultural. Barcelona: Ariel, 239-254

ROOS, J. P. (1996) Mitä on elämänpolitiikka? Sosiaalipolitiikan ja sosiaalityön tutkimuksen aikakauskirja JANUS numero 3. 1996, 210-223.

SALLILA, Pekka ja VAHERVA, Tapio (1998). Arkipäivän oppiminen. Aikuiskasvatuksen 39. vuosikirja. Helsinki: Kansanvalistusseura ja Aikuiskasvatuksen Tutkimusseura.

SILJANDER, Pauli (1987) Johdatusta henkitieteelliseen pedagogiikkaan, Acta Universitas Ouluensis. Series E No5.

THIERSCH, Hans (1986) Die Erfahrung der Wirklichkeit, Weinheim und München: Juventa.

UCAR, Xavier (1992) La animación sociocultural, Barcelona: CEAC.

VENTOSA, Victor Juan (1993) Fuentes de la animación sosciocultural en Europa, Madrid: Editorial Popular.

Artikkeli saapui toimitukseen 3.3.2000. se hyväksyttiin julkaistavaksi toimituskunnan kokouksessa 20.3. 